\title{
REGIONAL INEQUALITIES IN EUROPEAN UNION AND POTENTIAL IMPACTS OF EUROPEAN UNION MEMBERSHIP PROCESS ON REGIONAL DISPARITIES IN TURKEY*
}

\author{
Cihan KIZIL ${ }^{1}$
}

\begin{abstract}
Although the European Union contains many developed countries, it is a union which experiences various problems originating from regional differences. After each enlargement process, less developed countries which have significant regional disparities joined the Union. In parallel with these enlargements, regional inequalities became a greater issue, and it was required to address regional policies once again. The European Union attaches great importance on reducing regional inequalities. In order to reduce these inequalities, various funds are provided and numerous projects are carried out. However, regional inequalities continue and in some instances, it is observed that regional disparities even increase despite the attempts aimed at regional development. Following the officially recognition as a candidate for full membership, Turkey brought various regulations into effect in line with European regional policies and addressed regional problems more intensely. Even though Turkey started to put emphasis on regional policies, regional disparities become more apparent in the last years. Within the scope of this framework, how regional disparities change in the European Union member states will be investigated first. In the light of these examples, this study aims to anticipate the impacts of Turkey's accession process and possible membership to the Union. The analysis results show that not all countries benefit from the European Union considerably. Even in instances that are observed positive impacts in general economic situation, regional differences might increase. It is considered that Turkey will experience both positive and negative effects in this accession process.
\end{abstract}

Keywords: Regional Development, Regional Disparities, Regional Policy, European Union

JEL Code: R11, R58.

\section{Introduction}

European Union (EU) consists of various countries and keeps on expanding by way of the accession of new member states. This is why the EU has more extensive regional problems than Turkey. Just like terror in Turkey, the EU has its own regional problems. However, putting aside the EU's requirements of cross-border cooperation and Turkey's terror problem, one might say that the EU and Turkey are experiencing similar issues. These problems are the presence of under-developed rural areas and overcrowded areas and the decline in basic industries observed in certain areas. Turkey's EU candidacy and starting of the regulations required by the harmonization process will assimilate Turkey's approach systematics to these common problems with the EU. In this regard, the changes experienced by the countries after becoming members of the EU and the results created by the EU's regional policies are critical in predicting what Turkey might experience in the future. To make these evaluations, the study will analyze the changes in general and regional development experienced by the EU members.

\footnotetext{
This article is based on the author's PhD dissertation.

1 Res. Asst. Dr., Istanbul University, kizilc@istanbul.edu.tr
} 


\section{Regional Problems in the EU}

Just as in many countries, the countries in the EU are currently facing regional development problems. This problem, which used to be the countries' domestic affairs, took on a completely new dimension after the establishment of the EU. There are significant regional inequalities within the borders of the EU members and between each other. These regional problems in the EU can be handled under four headings; under-developed rural areas, decline of basic industries, congested areas and frontier areas (Hitiris, 2003: 226-230).

According to the OECD definitions, the majority of the EU consists of rural or moderately rural areas; in fact, in most of the Eastern European countries, only the capitals are characterized as urban areas (European Commission, 2008: 5). Even though there are examples such as the Netherlands that carry out agricultural production with high added value, the production in under-developed rural areas where production and employment is dependent on agriculture is carried out on infertile land, devoid of advanced technology and with a labor-intensive system.

The aggregation of some sectors in certain regions for historical and economic reasons can be observed very often. However, in time, these regions can go through a transformation process called "deindustrialization" caused by the decline in industrial capacity or activities (Skuflic ve Druzic, 2016: 993). It can be said that the iron-steel, textiles, shipbuilding, coal and chemical industries in Europe have shifted towards regions outside of Europe with low labor costs. It is also worth mentioning that the labor demand in regions with labor-intensive production is decreasing due to the decrease in demand to certain goods, increase in mechanization after technological developments and mineral resource depletion (Hitiris, 2003: 228).

Just like how the undeveloped regions become desolated through emigration, there are also problems brought forward by the capital accumulation and areas of specific population density. Agglomeration of economic activities in certain cities cause traffic, environment and noise pollution, congestion and similar urban problems. While overcrowded cities grow by drawing resources from other regions, this growth gradually turns into an unplanned growth and causes the current infrastructure to fall short. Even though the agglomeration may cause positive externalities in certain regions, the transformation of this situation to over-density causes negative externalities.

In addition to the urban problems caused by the companies and population clustering in certain regions, there are other points that need to be considered. Construction of houses, hospitals, schools, roads etc. in congested regions is much more expensive compared to the regions with less density. While congested regions draw resources to themselves, this causes the projects to become more costly. Considering the economic aspect, it may also cause the inability to reach the potential welfare (Holland, 1976: 3).

The expectation that the production factors will be more mobilized among neighboring countries and more economic relations and trading will be established between the member countries is one of the most influential considerations in the establishment of the EU. However, the fact that there are no cross-border infrastructures adjoining the previously-separated nation states causes the inability to see the desired development within the borders of the EU. Another problem is the fact that the trading activities in the regions surrounding the Union and geographically setting the borders of the EU are shifting towards more central regions with the emergence of the single market (Hitiris, 2003: 229-230). The least developed countries in the Union and the 
least developed regions of the member states are located in the outer regions of EU goes to show that the external border regions are experiencing economic problems.

Another problem encountered in the external border regions of the Union is the shift of the productive population in these regions towards other countries in the Union. This is caused by the economic activities being directed towards the center of the Union and the removal of the obstacles in front of population movements being removed with EU membership. According to the OECD statistics in 2014, the rates for population living outside of their countries is $17.5 \%$ in Ireland, $14 \%$ in Portugal and $6.6 \%$ in Greece. This rate was determined as $4.4 \%$ for Turkey in 2014. It is also known that there is an increasing trend of brain drain from our country within the last few years. According to the International Migration Report published by TÜiK, the number of people that emigrated from Turkey showed a significant increase of $42.5 \%$ between 2016 and 2017.

\section{Regional Development Efforts in Turkey and the EU}

The biggest project created by Turkey to solve the regional issues and invigorate the national economy is the Southeastern Anatolia Project (GAP). The first steps for GAP were taken in the 1970s with the irrigation and hydroelectric projects started in Euphrates and Tigris rivers. In 1989, GAP turned into a multi-sector, socio-economic development project. Compared to its equivalents in the world in terms of the geographic area, physical dimensions and goals, GAP emerges as an ambitious project (Ersungur, 2016: 322-323). However, the fact that this project was unable to reach full activity for many years caused the expectations to be left unfulfilled and the desired results were not obtained. In addition to the GAP project, created to ensure the development of Southeastern Anatolia, other projects were created for other regions of Turkey that rank low in terms of development, with the most significant ones being the Eastern Anatolia Project (DAP) and the Eastern Black Sea Project (DOKAP).

In addition to the development projects carried out by Turkey with its own efforts, there are other regional development and cross-border cooperation programs conducted within the scope of the financial cooperation between Turkey and the EU. The projects are as follows (Kılınç Savrul, 2012: 356-368; Dinler, 2014: 243-244):

- Eastern Anatolia Development Program in Bitlis, Muş, Hakkâri and Van

- TR82, TR83 and TRA1 Level-2 Regional Development Program,

- TRA2, TR72, TR52 and TRB1 Level-2 Regional Development Program,

- TR90 Level-2 Regional Development Program,

- GAP Regional Development Program,

- Joint Operational Program Black Sea Basin,

- Bulgaria-Turkey IPA Cross-Border Cooperation Program.

Turkey's candidacy in the EU has brought together a transformation that will cause the regional policies post-2000 to be separated from the periods before. This transition has especially shown itself in the ensuring of corporate structuring, subjecting policies and resources to certain criteria and local actors being more active in regional development projects. As a part of this change, the Regional Development Agencies (RDAs) are key organizations that have important roles in the application of the new regional development policies replacing the former regional development policies aiming for infrastructure and industrialization and instead aiming for 
information technologies, innovation, human capital and increase of competitiveness.

The first RDAs established in Europe after World War II were established in the 1950s in Austria, Belgium, France and Ireland. These countries were followed by Germany, the Netherlands, Italy and England in the 1960s and by Denmark, Finland, Greece and Spain in the 1980s (Özen, 2005: 4). The biggest reason for the status of the RDAs as widespread and important organizations in our country and the EU members countries is that the use of EU funds is made through the programs established by the RDAs. The EU's financial and technical assistance was benefited from in the establishment of these agencies in the 1990s in countries such as Sweden, Portugal, Poland and Slovakia (Meriç and Can, 2011: 188). Establishment of RDAs in all Level-2 regions of Turkey was completed in 2009, making Turkey one of the countries with the latest RDA structuring.

The number of projects the EU has conducted through the RDAs and supported within the scope of the regional development programs can be expressed in hundreds of thousands. Even though it is hard to specify all of these projects, it can be noted that 380 programs financed through structural funds between 2014 and 2020 in 209 regions of 28 member countries. The EU member state that benefits the most from the funds and investments is Poland with 77.5 billion euros. Poland is respectively followed by Italy, Spain, Romania and Czechia. The top ten regions receiving the most financial support are as follows: Slaskie (Poland), Hrvatska (Crotia is a region of its own), Norte (Portugal), Mazowieckie (Poland), Lietuva (Lithuania is a region of its own), Malopolskie (Poland), Andalucía (Spain), Wielkopolskie (Poland), Sicilia (Italy) and Campania (Italy). ${ }^{2}$

One of the most significant features of the EU programs is that the priorities and expectations are stated rather clearly. For example, the "Infrastructure and Environment Operational Program" in Poland, the biggest program of the 2014-2020 period, redirects about $64 \%$ of the allocated resources to transportation infrastructure, $15 \%$ to low carbon economy and more than $12 \%$ to climate change, risk aversion, management and environmental protection. In return for these fund flows, the expectations include increasing the share of renewable energy in total energy consumption to $15 \%$, decreasing greenhouse gas emission by $20.6 \%$ compared to the level in 1990 and decreasing the travel times for trains and highways between big cities to 3.7 hours. Other examples of the big programs currently ongoing within the EU are the "Large Infrastructure Operational Program" in Romania, "Smart Growth Operational Program" in Poland, "Economic Development and Innovation Operational Program" in Hungary. ${ }^{3}$

\section{Results of the EU's Regional Policies and Turkey}

The efforts of development in Turkey and the EU aim to have under-developed regions advance and decrease the imbalances between the regions by providing support in different areas. In line with this purpose, the EU provides high amounts of support to both the member states and the countries with membership potential. Benefiting from the EU funds, Turkey also allocated resources from its national budget and focused on this goal even more in the period after the year 2000. However, in spite of the positive results obtained in Turkey and the EU, there are negative ones as well.

\footnotetext{
2 These numbers and information were obtained from the statistics collected from the SFC2014 database on http://s3platform.jrc.ec.europa.eu/esif-viewer (Date accessed: 20.02.2019)

3 http://ec.europa.eu/regional_policy/en/atlas/programmes/ (Date accessed: 20.02.2019)
} 
When we look at the EU countries, we can see that France, one of the founding countries, is much less wealthier compared to 1991. This situation is even more problematic in Italy. Even though it managed to display rapid convergence up to the 2008 Crisis, Spain, joining the Union later on, has struggled to recover after this period. Those who benefited the most from the transition to the Common Market have been small yet already rich countries such as Denmark, Austria and the Netherlands. Countries such as Sweden, Finland and Belgium have also prospered compared to the EU-15 average. In this process, those who suffered the most have been Italy, followed by Portugal and Greece. In the following period, it is predicted that the welfare in Italy and France, two of the biggest economies in the EU, will continue to shrink and the gap between Germany and other rich economies will be even wider. Countries in Eastern Europe are expected to continue their convergence with the other economies (Tilford, 2017). Therefore, it is difficult to speak of a convergence or divergence within the EU covering every region and period.

The GDP values and change rates per capita of the five EU members in NUTS Level-2 regions are summarized in ANNEX 1. In addition to Spain and Italy, who have a scale and socio-economic structure that can be compared with Turkey and have been implementing EU's regional policies for many years, countries of Hungary, Poland and Czechia that joined the EU with the expansion in 2004 are also included in this table. When we compare the values in 2007 and 2016, we can see that the GDP per capita in Italy and Spain have increased at very small rates; however, the three relatively-new members of the Union have scored significant increases within a 10-year period. Benefiting the most from the EU funds, the high GDP per capita increase of $35.4 \%$ in Poland is especially interesting. This increase was respectively $24.6 \%$ and $13.7 \%$ in Czechia and Hungary, which joined the EU in the same year as Poland and are relatively smaller.

When we look at the statistics of the five countries, it can be observed that the countries that joined the EU later on scored more positive results in terms of general and regional economic growth. Even though they have been benefiting from the EU funds for longer periods of time, the economic crises of Spain and Italy are rather apparent in the statistics. The fact that these two countries showed decline instead of advancement in the regions is thought-provoking, considering the amounts spent for the EU's regional policies. In some cases, the works carried out for the development of a certain region prevents the development of the other ones by causing their resources to be drawn to that region and creating "backwash effect".

\section{Conclusion}

Even though Turkey realized mega projects such as GAP to solve its significant regional differences, it is still unable to prevent the increase in regional disparities. One of the biggest reasons for this increase is that a systematic and consistent approach could not be established for regional problems. Going through a transformation in its regional policies after its candidacy to the EU becoming official, Turkey has started to carry out regulations in line with the EU. Starting with the foundation of the development agencies, the initiation of the institutionalization and systematic regional policy implementations lacked in Turkey is one of the positive results brought to Turkey by the EU candidacy. However, the internal results of the policies vary, just like the results in the EU. It is predicted that the EU membership process and a potential EU membership will have rather variable effects on Turkey. When we look at the EU, we can see that the economic activities keep shifting from geographically peripheral regions towards the center and the countries far from the center of the Union are losing qualified labor force and capital. 
Considering the continuous increase in brain drain, it is highly possible that the removal of the boundaries between the EU and Turkey will create similar results for Turkey. While significant advances can be observed in the economies of the countries that joined the EU with the latest expansions, it is also apparent that most of them are experiencing increasing regional inequalities. Since Turkey's full membership to the EU will allow new EU funds to enter the country and the foreign capital to increase, there can be improvements in the general economic indicators. However, the fact that the regional differences experienced by the countries that joined the EU with the latest expansions are becoming even more apparent will most likely cause even worse results in Turkey, which is already experiencing significant imbalances between metropolitan and non-metropolitan areas.

\section{References}

Dinler, Z. (2014). Bölgesel iktisat, Bursa: Ekin Kitabevi.

Ersungur, Ş. M. (2016). Bölgesel Iktisat: Teori, Politika ve Uygulama, Ankara: İmaj Yayınevi.

European Commission. (2008). "Poverty and Social Exclusion in Rural Areas", http://ec.europa. eu/social/BlobServlet?docld=2087\&langld=en, (23.02.2019).

Hitiris, T. (2003). European Union Economics, London: Prentice Hall.

Holland, S. (1976). The Regional Problem, London: The Macmillan Press.

Kılınç Savrul, B. (2012). "Türkiye-Avrupa Birliği Mali İşbirliği Kapsamında Bölgesel Kalkınma Programlarının Etkinliği”, İstanbul Üniversitesi İktisat Fakültesi Mecmuası, 62 (2), s.355 - 371.

Meriç, M. ve Can, E.: 2011 "Bölgesel Kalkınmada Kalkınma Ajansları Modeli: İzmir Kalkınma Ajansı", 26. Türkiye Maliye Sempozyumu Tebliğ Kitabı, s.185- 204.

Özen, P. (2005). “Avrupa'da Bölge Kalkınma Ajansları", http://www.tepav.org.tr /upload/files/1271245092r8246.Bolgesel_Kalkinma_Ajanslari.pdf, (23.02.2019).

Skuflıc, L. \& Druzıc, M. (2016). "Deindustrialisation and Productivity in the EU”, Economic Research-Ekonomska Istraživanja, 29 (1), s. 991-1002.

Tilford, S. (2017). "Is the EU's Single Market Leading to Convergence or Divergence?", http:// www.cer.eu/insights/eus-single-market-leading-convergence-or-divergence, (20.02.2019). 


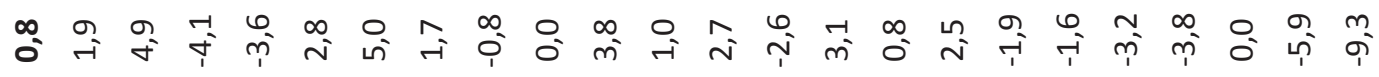

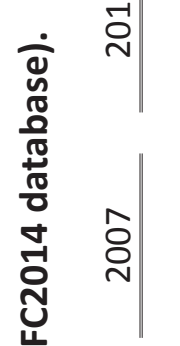

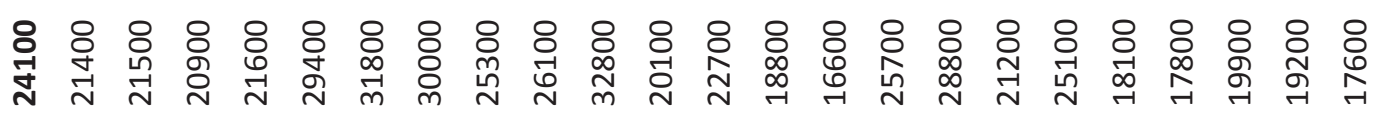

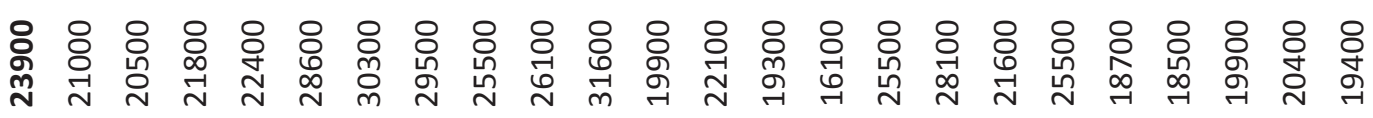

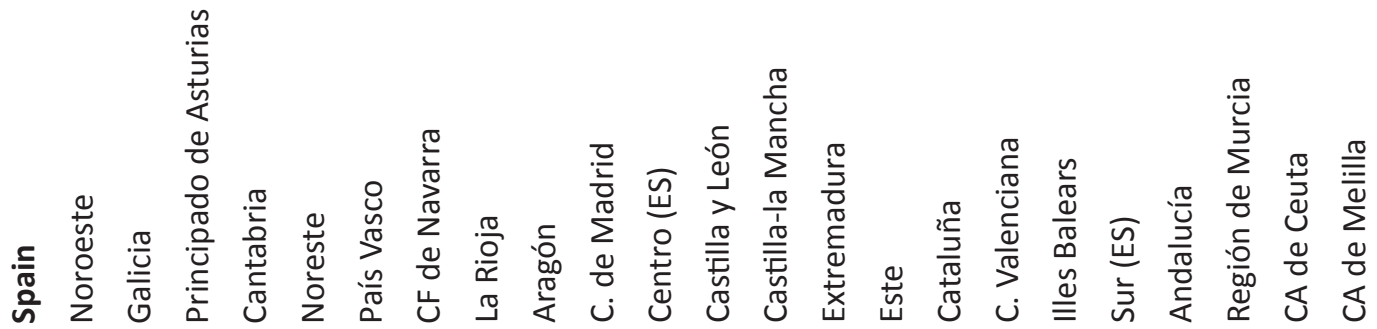

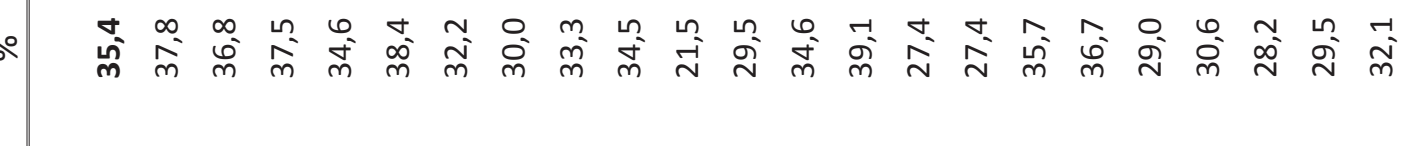

$\sum_{0}^{+1}$

y

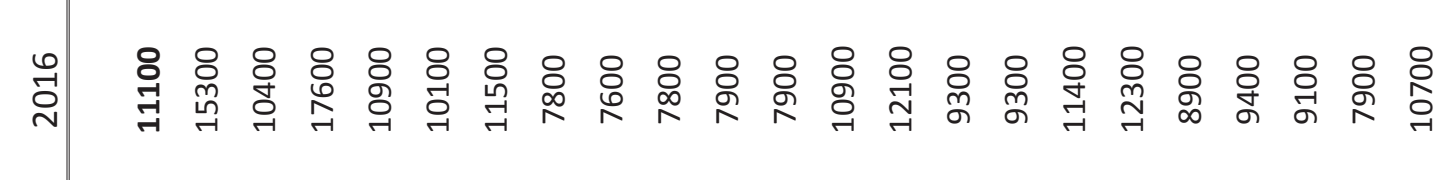

인

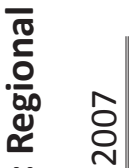

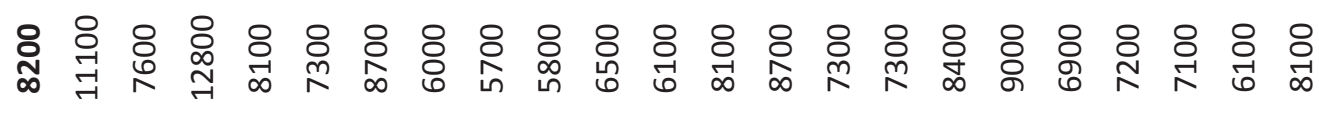

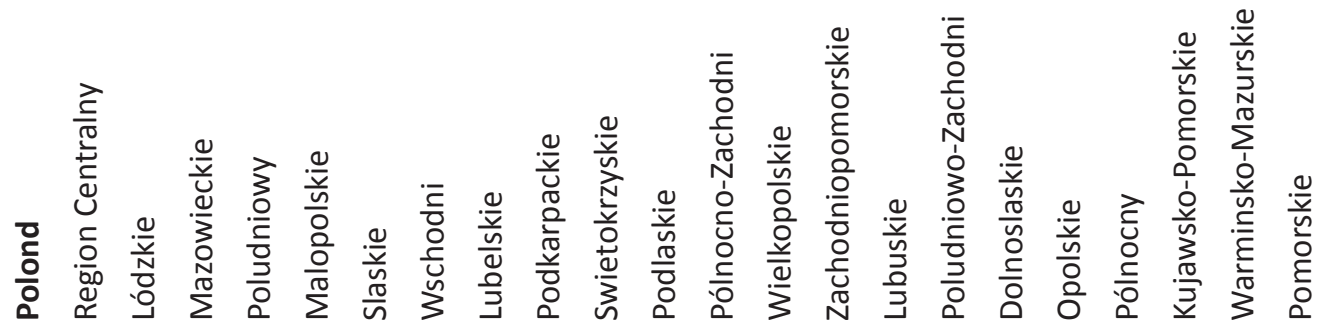




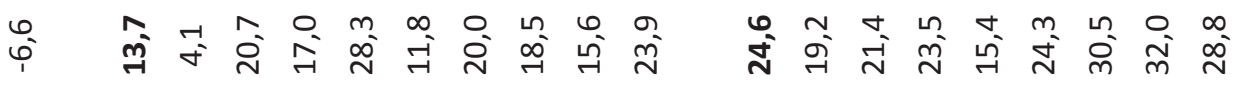

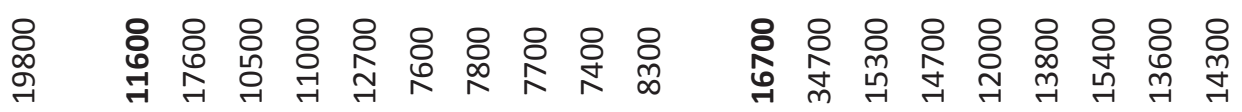

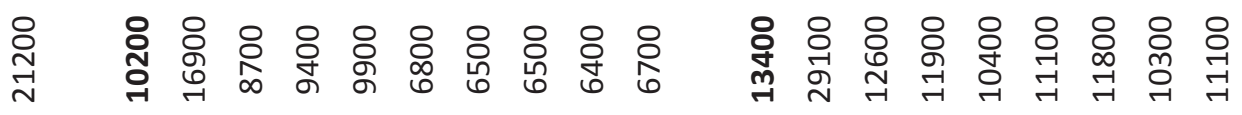

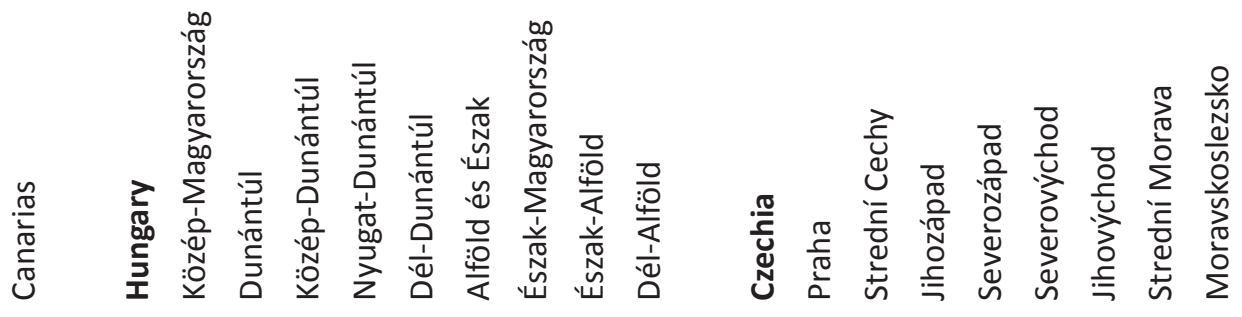

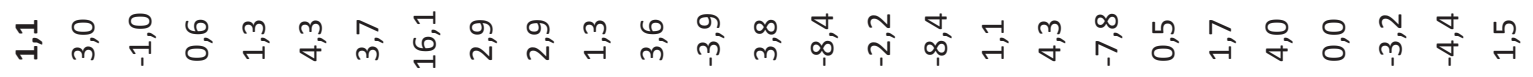

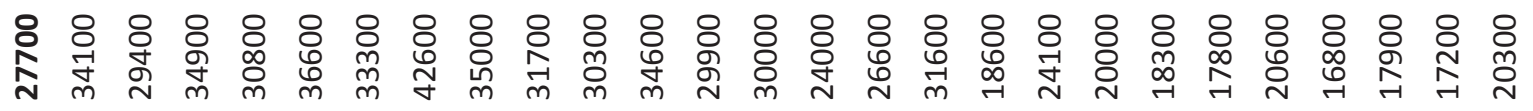

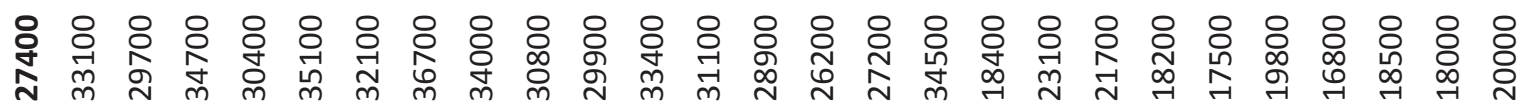

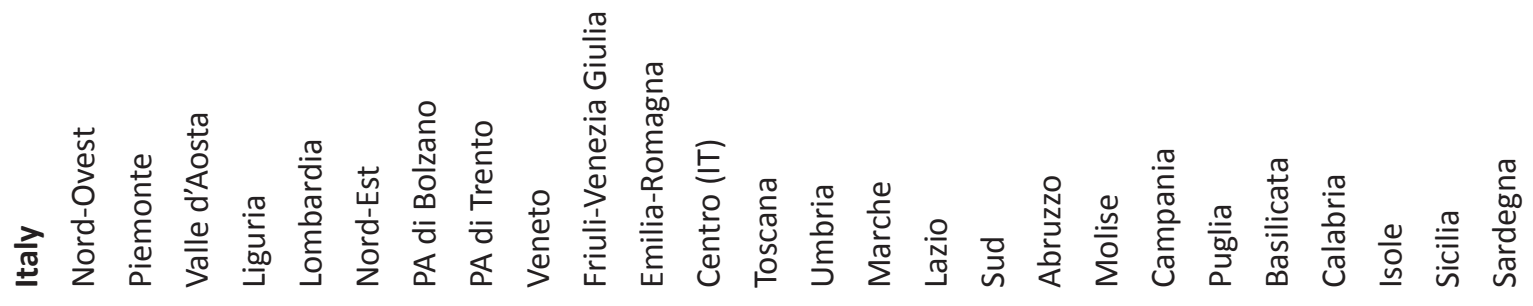

